\title{
Amazon's Decision about Entering Pharmacy Business, is this Going to Affect Other Retail Pharmacy Chains?
}

\author{
Fadi Al Daoud* \\ Trauma research coordinator, Hurley Medical Center, USA
}

Received: 㘹June 27, 2018; Published: 紫July 09, 2018

*Corresponding author: Fadi Al Daoud, Trauma research coordinator, Hurley Medical Center, 7B trauma services, USA

\section{Opinion}

Amazon was in the process of taking a decision about entering the pharmaceutical industry through opening Amazon pharmacy retailer after the acquisition of Whole Foods grocery stores last August.The grocery chain might soon house pharmacy locations. Read: (Is Amazon getting into the pharmacy business? This is what you need to know. By Emma Court [1]. According to Leerink Partners analyst Ana Gupte, there was concern and skepticism voiced regarding the threat that may occur on retail pharmacy chains such as CVS, Walgreen and Walmart should Amazon decide to tap the pharmaceutical industry.Most of the retail pharmacies like Wal-Mart, CVS and Walgreens have long standing customers who may likely remain loyal to their pharmacy and may not make the switch.In addition, many consumers to date do not engage in online retail and thus may not make the switch to Amazon online pharmacy. If anything, Amazon's potential of becoming a pharmacy retailer may only enhance the pharmacy retail services by offering affordable pricing to those consumers who otherwise cannot afford medications, especially Amazon may pursue a mail-order pharmacy that initially targets uninsured customers or people who have high deductibles and pay cash for most of their prescription drugs.

See: (Amazon Could Be Targeting Pharmacy Delivery Business. investors.com by BRIAN DEAGON[2]. This may lead to an improvement in medication compliance and better disease management.This was evident in their acquisition of Whole Foods as it made the desirable organic grocery chain more affordable to those consumers who may have not been able to shop there previously.In one particular article published by Kevin Granville[3] in the New York Times ("The Amazon Effect: How Prices Dropped at Whole Foods"), was able to show a comparison of the same items bought prior to the acquisition and after the acquisition revealed an overall savings of $14 \%$. Additionally, should Amazon decide to join the pharmaceutical arena this would increase the work force with the addition of new jobs. The potential Amazon pharmacy retailer could also help the struggling smaller pharmaceutical retailers by acquiring them and thus expanding pharmaceutical services. In general, there should be less skepticism and rather an effort to support Amazon in opening a pharmaceutical chain as this would lead to affordable medication cost to consumers as a whole.

\section{References}

1. (2017) Emma Court, Is Amazon getting into the pharmacy business? This is what you need to know.

2. (2017) Brian Deagon, Amazon Could Be Targeting Pharmacy Delivery Business.

3. (2017) Kevin Granville, The Amazon Effect: How Prices Dropped at Whole Foods.
ISSN: 2574-1241

DOI: $10.26717 / B J S T R .2018 .06 .001363$

Fadi Al Daoud. Biomed J Sci \& Tech Res

(C) This work is licensed under Creative

Submission Link: https://biomedres.us/submit-manuscript.php

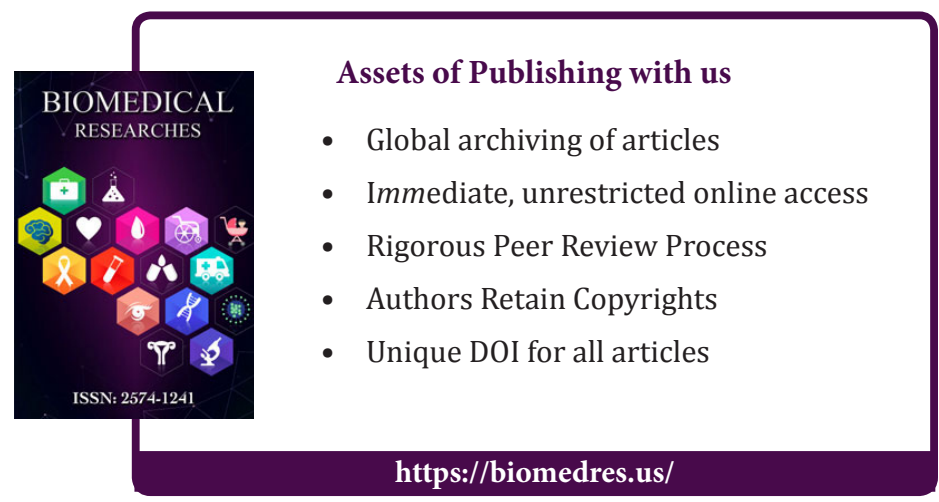

